ADAM LITYŃSKI (Katowice)

\title{
Narody w Rosji 1917 r. Skutki rewolucji. Uwagi na kanwie książki Richarda Pipesa Czerwone imperium. Powstanie Zwiazku Sowieckiego, tłum. W. Jeżewski, Wyd. Magnum, Warszawa 2015, ss. 363
}

I. „Pierwszym skutkiem rewolucji rosyjskiej stał się upadek caratu, a jej ostateczną konsekwencją było zupełne załamanie się wszystkich form zorganizowanego życia w Rosji. Do wielu aspektów tego załamania należał rozpad imperium (...)" - napisał Richard Pipes w swojej najstarszej książce, a najpóźniej, właśnie niedawno, wydanej w Polsce. Słowa te autor odniósł tylko do okresu tworzenia Związku Socjalistycznych Republik Radzieckich, do lat 1917-1922, ale jakże dobrze można je odnieść do całych 74 lat istnienia czerwonego imperium. Wydanie polskie to tłumaczenie drugiego wydania, znacznie późniejszego niż pierwsze, książki opublikowanej przez Harvard University Press. Autor - urodzony (1923) w Cieszynie amerykański historyk i politolog - jest dobrze znany czytelnikom polskim, zwłaszcza historykom, z licznych thumaczonych na język polski prac na tematy rosyjskie, głównie dotyczące rewolucji 1917 r. Szerszej opinii publicznej dał się zapamiętać jako ten, który w aureoli byłego doradcy ds. bezpieczeństwa prezydenta USA publicznie wypowiadał się przeciwko przyjmowaniu Polski i innych krajów Europy środkowo-wschodniej do NATO wówczas, gdy sprawa ta się ważyła.

Rozdział pierwszy jest wprowadzającym do głównego tekstu. Nie tylko dlatego, że traktuje o kwestii narodowej w Rosji przed 1917 rokiem, lecz także dlatego, że przede wszystkim poświęcony został analizie programów partii politycznych w kwestii narodowej w przededniu rewolucji. Czytelnik otrzymuje prezentację programów wszystkich najważniejszych partii w Rosji carskiej, ale ze szczególnym uwzględnieniem koncepcji Lenina w tej materii, czyli w konsekwencji programu SDPRR $(b)^{1}$. Pisywano w Polsce na temat

${ }^{1}$ Socjaldemokratyczna Partia Robotnicza Rosji - założona w 1898 r. na zjeździe w Mińsku. Szczególnie ważną rolę w jej skonsolidowaniu i opracowaniu programu miała założona w $1900 \mathrm{r}$. 
Leninowskiej myśli sporo (zwłaszcza Marek Waldenberg, Andrzej Walicki, Wiktor Suchecki, także inni), ale oczywiście zawsze warto zapoznać się z tym, jak sprawę widzi znany historyk zza oceanu. Skonstatować należy, że nie ma między nami różnic, gdy Autor w konkluzji pisze, że „Lenin traktował problemy narodowe jako coś, co należy wyzyskać, a nie coś, co trzeba rozwiązać" (s. 51). Podobnie trzeba się zgodzić z Richardem Pipesem, gdy na czoło swojej pracy wybija stwierdzenie należące do wniosków: „W ciągu niecałego roku po abdykacji cara kwestia narodowa wysunęła się na czoło zagadnień rosyjskiej polityki” (s. 52). To prawdziwa i ważna uwaga; zauważmy, że bolszewicy robili rewolucję z hasłami w pierwszym rzędzie społecznymi, bo taki wszak był ich program, ale od pierwszych tygodni (nie miesięcy!) przyszło im zmierzyć się przede wszystkim z problemami narodowymi. Zauważmy jeszcze więcej: dokładnie z tymi samymi problemami przyszło też zmierzyć się białym. Tylko czerwoni zgrabniej się za nie zabrali, oszukując wszystkich, czego biali nie chcieli robić. I to była absolutnie najgłówniejsza przyczyna klęski białych.

Podstawowa i objętościowo największa część monografii Richarda Pipesa skonstruowana została w ten sposób, że Autor omawia temat w układzie terytorialnym, tzn. prezentuje przebieg wydarzeń w poszczególnych krajach i regionach byłego imperium rosyjskiego. Omówienie - z pewnością zamierzone przez Autora - nie jest jednak poprowadzone z jednakową szczegółowością. Autor zdecydowanie preferował w Europie Ukrainę i Białoruś, Azję środkową (tereny dzisiejszego Kazachstanu, Uzbekistanu i in.), Zakaukazie i Kaukaz Północny. W minimalnym zakresie, niekiedy wręcz tylko wzmiankami, potraktowane zostały zwłaszcza kraje bałtyckie, łącznie z Finlandią; w isto-

przez Lenina gazeta „Iskra”. Drugi Zjazd SDPRR (Bruksela-Londyn 1903) w toku ostrych dyskusji uchwalił program partii, ale owe dyskusje doprowadziły do powstania dwóch ugrupowań: bolszewików i mienszewików, których ostateczne zerwanie nastąpiło w 1912 r., kiedy to na konferencji w Pradze wybrano wyłącznie bolszewicki Komitet Centralny $z$ Leninem na czele. Bolszewicy występowali odtąd jako SDPRR (bolszewików). Partia była oparta na silnej centralizacji i ostrej dyscyplinie wewnętrznej. W marcu 1918 r. na III Zjeździe nastąpiła zmiana nazwy partii na Rosyjską Komunistyczną Partię (bolszewików). Na X zjeździe RKP(b) w marcu 1921 r. wprowadzony został zakaz tworzenia frakcji w partii, co stało się wielkim ułatwieniem dalszej ewolucji w kierunku tzw. stalinizmu. Frakcje mogły być przynajmniej skromną namiastką wielopartyjności w państwie. Na posiedzeniu KC w kwietniu 1922 r. ustanowiono stanowisko sekretarza generalnego, które z rekomendacji Lenina powierzono Stalinowi. Nie istniało stanowisko przewodniczącego partii; niekwestionowanym liderem był Lenin. W grudniu 1925 r. nastąpiła zmiana nazwy na Wszechzwiązkową Komunistyczną Partię (bolszewików) W październiku 1952 r. zmieniono nazwę na Komunistyczną Partię Związku Radzieckiego, a w miejsce sekretarza generalnego wprowadzono I sekretarza, zaś od 1966 r. znowu sekretarza generalnego. Wówczas też w miejsce Biura Politycznego wprowadzono Prezydium KC. W Prezydium - na wniosek Stalina - wyodrębniono jeszcze Biuro Prezydium. W ścisłym Biurze Stalin wyodrębnił jeszcze ,piątkę” głównych członków Prezydium (Stalin, Malenkow, Beria, Bułganin, Chruszczow). Komunistyczna Partia Związku Radzieckiego została w Rosji zdelegalizowana przez Jelcyna bezpośrednio po sierpniowym ,puczu Janajewa” (24 sierpnia 1991 r.). Do końca 1991 r. pozostałe b. republiki zdelegalizowały KPZR. 
cie nie ma też Polski. To logiczne, skoro w tytule książki Autor zakreślił, że dzieło ma za przedmiot „,powstanie Związku Sowieckiego”. Wszak kraje bałtyckie i Polska szczęśliwie nie weszły wówczas w skład Rosji radzieckiej, a wkrótce później ZSRR.

Właśnie dlatego, że wspomniane kraje bałtyckie w zasadzie w książce Richarda Pipesa zostały niemal pominięte, w niniejszym omówieniu warto o nich trochę powiedzieć.

II. O Finlandii Richard Pipes napisał jedną stronę (s. 3-4). Finlandia należąca wcześniej do Szwecji ${ }^{2}$ - stała się częścią imperium rosyjskiego w 1809 roku w wyniku wojny szwedzko-rosyjskiej, będącej fragmentem wojen napoleońskich. Uzyskała status wielkiego księstwa złączonego unią personalną z cesarstwem rosyjskim (każdorazowy car był wielkim księciem Finlandii); istniał wybierany w wyborach powszechnych parlament fiński o dość dużym zakresie uprawnień ustawodawczych, ale z koniecznością sankcji monarchy, zachowano odrębny system administracji, ale monarcha mianował generał-gubernatora o kompetencjach jednak znacznie mniejszych aniżeli inni generał-gubernatorzy na kresach (stał na czele wojska oraz policji na terenie Finlandii), utrzymano samorząd, sądownictwo, zachowane zostały dawne szwedzkie prawa cywilne i karne, religia luterańska, utrzymano granicę celną z Rosją. Finowie nie podlegali obowiązkowej służbie wojskowej. Finlandia korzystała z obrony ogólnopaństwowej rosyjskiej. Z Turku do Helsinek stolica została przeniesiona w 1812 roku. W sumie Wielkie Księstwo Finlandii było autonomiczną częścią Cesarstwa Rosyjskiego. Nasuwa się tu skojarzenie z pierwszymi latami Królestwa Polskiego. Polityka Mikołaja II na przełomie XIX i XX wieku, zmierzająca do likwidacji autonomii (1899) i odrębności ustrojowych Finlandii, została przerwana wybuchem rewolucji 1905-1907. W warunkach zagrożenia praw Finlandii oraz frontowych sukcesów niemieckich i niemieckich obietnic pomocy dla Finlandii (dostaw broni, a nawet pomocy interwencji zbrojnej), wreszcie wraz z utratą stabilności państwa rosyjskiego, nie mogły być zaskoczeniem proniemieckie klimaty.

Obalenie caratu i powołanie Rządu Tymczasowego przyniosły Finlandii ważne i odczuwalne zmiany. Dnia 6 grudnia 1917 r. parlament fiński proklamował niepodległość Finlandii jako republiki. Na początku 1918 r. niepodle-

2 Warto w tym miejscu dodać, że po raz pierwszy granica wschodnia Finlandii ustalona została w XIV w., w wyniku wojen między Szwecją a Nowogrodem Wielkim. W pokoju w 1323 r. ustalono rozgraniczenie linią biegnącą od Przesmyku Karelskiego przez Karelię w kierunku północ północny-zachód do północnych krańców Zatoki Botnickiej. Finlandia przypadła wówczas Szwecji. Granica biegnąca od Karelii do brzegów Morza Barentsa ustalona została w 1595 r. po trwającej blisko ćwierć wieku „wojnie nienawiści” z Wielkim Księstwem Moskiewskim. W ten sposób też nakreślony został trwale nie tylko zarys granicy, lecz także wpływ dwóch kultur, w tym religii. T. Cieślak, Historia Finlandii, Wrocław-Warszawa-Kraków-Gdańsk-Lódź 1983, s. 32, 73, passim; Wielka Encyklopedia Powszechna. PWN [WEP], Warszawa 2001-2005, tutaj t. IX, s. 136. 
głą Finlandię uznały radziecka Rosja ${ }^{3}$, Niemcy, Francja i inne państwa. Uznanie przez sowiecką Rosję było wynikiem żądania niemieckiego, postawionego w toku rokowań pokojowych w Brześciu. Czerwoni, przy wsparciu nadal stacjonujących w Finlandii oddziałów rosyjskich (teraz będących jednostkami rządu sowieckiego), utworzyli rząd w Helsinkach i opanowali południową część kraju. Garnizony wojsk sowieckich w Finlandii wkrótce powstrzymały się jednak z jawną interwencją, ponieważ kolidowało to $\mathrm{z}$ prowadzonymi w Brześciu rokowaniami pokojowymi Sowietów z Niemcami. Zorganizowane i dowodzone przez C.G.E. Mannerheima ${ }^{4}$ wojska białych z pomocą korpusu ekspedycyjnego niemieckiego pokonały (kwiecień-maj 1918 r.) siły czerwonych. Zbawienne dla Finlandii było okresowe zerwanie przez Sowietów brzeskich rozmów pokojowych, bowiem to wznowienie ofensywy niemieckiej w połowie lutego 1918 r. pozwoliło wojskom niemieckim uderzyć na czerwonych i pomóc w oswobodzeniu od nich Finlandii. W traktacie brzeskim (3 marca 1918 r.) strona rosyjska zobowiązała się, że nie będzie ingerować w sprawy Finlandii.

Przegrana Niemiec w I wojnie położyła kres wzrastającym wpływom niemieckim i spowodowała skierowanie uwagi fińskich sił politycznych w stronę zachodnich państw Ententy. W 1919 i 1920 r. cały czas trwały lokalne walki z Rosją sowiecką, zakończone (14 października 1920 r.) traktatem pokojowym w Dorpacie (Tartu), którym potwierdzono linię graniczną

${ }^{3}$ Rada Komisarzy Ludowych podjęła stosowną uchwałę 18/31 grudnia 1917 r.; uchwała zatwierdzona została przez WCKW 4 stycznia 1918 r. (22 grudnia 1917 r.). История советской конституции. Сборник документов. 1917-1957, Издательство Академии Наук СССР, Москва 1957, s. 36; zob. też История советской конституции (в документах) 1917-1956, Государственное издательство юридической литературы, Москва 1957, s. 91.

${ }^{4}$ Mannerheim Carl Gustaf Emil: ur. 1867 k. Turku, zm. 1951 w Lozannie; pochodził z rodziny szwedzkiej osiadłej w Finlandii, baron, polityk, wojskowy, marszałek, prezydent Finlandii. Ukończył (1889) Mikołajewską Szkołę Kawalerii w Petersburgu, służył w Kawalerii gwardii; uczestnik wojny japońsko-rosyjskiej 1904-1905; od 1911 generał; m.in. stacjonował w b. Królestwie Polskim (Przywiślańskim Kraju) i tam nawiązał kontakty z polskim ziemiaństwem; podczas I wojny światowej dowodził korpusem; armię rosyjską opuścił w grudniu 1917 i wrócił do Finlandii. W styczniu 1918 mianowany dowódcą fińskich oddziałów samoobrony, przekształconych wkrótce w armię fińską (białych), którą dowodził w wojnie domowej (styczeń-maj 1918) przeciwko czerwonym (fińskim socjaldemokratom, a nie bolszewikom); złożył dymisję będąc przeciwnym wiązaniu się z Niemcami; listopad-grudzień 1918 za granicą prowadził działalność dyplomatyczną na rzecz uznania Finlandii; grudzień 1918-lipiec 1919 regent Finlandii; czynił starania o podjęcie działań wojennych przeciwko Rosji radzieckiej, do czego nie doszło; lipiec 1919 przegrał wybory prezydenckie; 1931-1939 przewodniczący rady obrony; z jego nazwiskiem słusznie wiąże się budowę fińskich umocnień obronnych nad granicą z ZSRR (słynna linia Mannerheima) i bohaterską obronę w tzw. wojnie zimowej po agresji ZSRR na Finlandię 30 wrzesień 1939; 30 listopada 1939-31 grudnia 1944 naczelny wódz armii fińskiej także w okresie wojny fińsko-radzieckiej 1941-1944, ale mimo nacisków niemieckich nie podjął ataku na Leningrad ani na kolej murmańską; po zawarciu rozejmu z ZSRR (19 września 1944) dowodził wojskami fińskimi w walce przeciwko Niemcom w Laponii; sierpień 1944-marzec 1946 prezydent państwa. Bohater narodowy, wielki autorytet, symbol niepodległości małego kraju. WEP XVI, s. 563; T. Cieślak, op. cit., s. 216 i n., passim. 
fińsko-rosyjską sprzed 1917 r. i przyznano Finlandii ważny rejon Petsamo (Pieczenga). Względnie łatwe oderwanie od Rosji białej i czerwonej i uzyskanie nigdy wcześniej nie doświadczonej przez Finów pełnej niepodległości Finlandia zawdzięczała szczęśliwemu zbiegowi kilku czynników. Położeniu geograficznemu, mądrym przywódcom politycznym, którzy szukali wsparcia w Niemczech, ale do czasu: tylko wówczas, gdy trwała jeszcze wojna światowa i wojska niemieckie były daleko na wschodzie, zbliżały się do stolicy Rosji władającej od 1809 roku Finlandią. Kiedy Niemcy w wojnie światowej padły, wówczas Finowie walczyli sami oraz szukali sprzymierzeńców na Zachodzie. Upadek Rosji i upadek Niemiec oraz własna walka przyniosły temu krajowi rzeczywistą i pełną niepodległość. Można w tych okolicznościach dopatrywać się pewnych podobieństw z sytuacją Polski, która jednak miała o tyle sytuację gorszą, że ze względów geograficznych dla bolszewików stanowiła bramę do Europy zachodniej - w pierwszej kolejności do zrewoltowanych Niemiec - którędy sowiecka Rosja miała pożar rewolucji rozpalić w całej Europie.

III. Jak wcześniej wspomniano, na temat krajów, które nie weszły w skład ZSRR, R. Pipes w zasadzie nie pisze. O Estonii w omawianej książce znaleźć można zaledwie wzmiankę w postaci jednego krótkiego zdania konstatującego, że „Estonia zerwała więzi z Rosją w lutym 1918 roku” (s. 110). Warto jednak zapytać i przypomnieć, jak do tego doszło i co działo się wcześniej.

Jesienią 1917 r. wojska niemieckie najpierw - błyskawicznym i nowatorsko prowadzonym atakiem ${ }^{5}$ - zdobyły Rygę (wywołując niebywałą panikę w wojsku rosyjskim), a następnie bez oporu zajęły największą estońską wyspę Ozylię, a potem cały archipelag estoński. Wówczas odczuwalne poczucie zagrożenia wojennego zaczęło się także przekładać na sytuację wewnętrzną: rosły wpływy bolszewików estońskich, którzy w swoim programie wzywali do zakończenia wojny i zawarcia pokoju. Po nadejściu wiadomości z Piotrogrodu o udanym zamachu stanu w stolicy Rosji miejscowi bolszewicy stopniowo opanowali całą Estonię. Zawarcie przez bolszewicką Rosję rozejmu z Niemcami wstrzymywało - chwilowo - od 5(18) grudnia 1917 r. działania zbrojne. Kiedy jednak rokowania pokojowe brzeskie zostały okresowo przez stronę radziecką zerwane (luty 1918 r.), Niemcy siłą 50 dywizji wznowili błyskawiczną ofensywę. Wojska niemieckie zbliżały się tak szybko, że Sowieci - jak wiadomo - przenieśli stolicę z grodu Piotra do Moskwy ${ }^{6}$, dalej od frontu. Wobec ciężkiej klęski Sowietów (także na terenie Estonii), tuż przed wejściem Niemców do Rewla (Tallina), 23-24 lutego 1918 r. powołany przez

${ }^{5}$ Bliżej zob. M.S. Neiberg, D. Jordan, Front wschodni 1914-1920. Od Tannenbergu do wojny polsko-bolszewickiej, słowo wstępne D. Showalter, tłum. J. Kozłowski, Poznań 2010, s. 142.

${ }^{6}$ История советской конституции (в документах) 1917-1956..., s. 116; История советской конституции. Сборник документов. 1917-1957 ..., s. 55. 
Estońskie Zgromadzenie Konstytucyjne komitet proklamował niepodległość Estonii.

Po porażce Niemiec w I wojnie i anulowaniu (13 listopada 1918 r.) przez Sowietów traktatu brzeskiego wojska radzieckie zaatakowały (22 listopada 1918 r.) Estonię i podjęły kroki w kierunku ustanowienia władzy sowieckiej$^{7}$. Rosyjska Rada Komisarzy Ludowych [RKL] na prośbę „władzy radzieckiej” Estonii uznała (7 grudnia 1918 r.) niezawisłość [независимость] Estońskiej Radzieckiej Republiki ${ }^{8}$. Estończycy stanęli do walki z Rosją radziecką. To jedyna zwycięska wojna w historii Estonii. Ostatecznie, 2 lutego 1920 r., zawarty został traktat pokojowy między Rosją radziecką a Estonią, w którym Rosja uznała niepodległość Estonii ${ }^{9}$.

Druga połowa 1919 r. to miesiące skrajnie trudne dla władzy radzieckiej; wydawało się, że nie ma szans na utrzymanie się bolszewików w Rosji. „Na wiosnę 1919 roku zaplanowano przeciwko Rosji Radzieckiej kombinowaną wyprawę Kołczaka-Denikina-Judenicza"10. Z południa niepowstrzymanie, jak burza, szedł na Moskwę Denikin. Od wschodu nacierały siły Kołczaka. Obaj biali generałowie stali na stanowisku jednej, niepodzielnej Rosji w granicach w zasadzie z 1914 r. Denikin głównie dlatego poniósł klęskę. Z terytorium Estonii w drugim półroczu (maj-listopad) 1919 r. atakowała w kierunku Piotrogrodu Armia Północno-Zachodnia, którą dowodził generał Rodzianko, zaś genenerał Judenicz sprawował dowództwo sił rosyjskich w całym rejonie północno-zachodnim.

IV. O wydarzeniach na Łotwie próżno by szukać wiadomości w książce Richarda Pipesa. Nie jest to zarzut: wszak Łotwa nie współtworzyła wówczas czerwonego imperium. Gdy wybuchła I wojna światowa, wojska niemieckie, już latem 1915 r., zajęły tereny łotewskie do Dźwiny (Kurlandię i Semigalię), na razie bez Rygi. Resztę nieokupowanych jeszcze ziem łotewskich wojska niemieckie zajęły w lutym 1918 r., gdy po zerwaniu przez stronę sowiecką brzeskich rozmów pokojowych Niemcy przypuścili potężny atak na całym froncie wschodnim. Natychmiast (17 listopada 1918 r.) po zakończeniu wojny światowej w Rydze ukonstytuowała się (74 przedstawicieli rozmaitych narodowych stronnictw politycznych) Rada Ludowa, która 18 listopada $1918 \mathrm{r}$. proklamowała niepodległość Łotwy i powołała rząd. Jak wiadomo, Sowieci jednostronnie ogłosili anulowanie traktatu brzeskiego (13 listopada $1918 \mathrm{r}^{11}$ ) i Armia Czerwona ruszyła na zachód w miarę opuszczania terenów przez wojska niemieckie. Dokładnie w miesiąc (17 grudnia 1918 r.) po proklamowaniu

\footnotetext{
7 Zob. История советской конституцчи. Сборник документов. 1917-1957..., s. 94-95.

8 История советской конституции. Сборник документов. 1917-1957..., s. 95-96.

9 J. Lewandowski, op. cit., s.181-182.

10 J. Stalin, Dzieła, t. 4, Warszawa 1951, s. 295.

11 История советской конституциии (в документах) 1917-1956..., s. 166-167.
} 
niepodległości Łotwy bolszewicy ogłosili ustanowienie władzy radzieckiej na Lotwie $^{12}$. Z tekstu dokumentu wynika, że ogłaszano republikę radziecką, ale niewchodzącą w skład sowieckiej Rosji. W kilka dni później (22 grudnia 1918 r.) Rada Komisarzy Ludowych sowieckiej Rosji ,na prośbę radzieckich władz Łotwy (...) uznaje niezawisłość [независимостъ] Radzieckiej Republiki Łotwy" " Zastosowano więc dokładnie ten sam schemat, co w przypadku Estonii. Tego samego dnia dokładna kopia dokumentu o uznaniu sporządzona została także dla Litwy ${ }^{14}$, zaś w 3 dni później raz jeszcze napisano, tym razem wspólny, dokument o podtrzymaniu uznania przez Wszechzwiązkowy Centralny Komitet Wykonawczy radzieckich republik Estonii, Łotwy i Litwy ${ }^{15}$.

Armia Czerwona wkroczyła (3 stycznia 1919 r.) do Rygi i prawie niezwłocznie (15 stycznia 1919) ustanowiony zjazd rad przyjął konstytucję Socjalistycznej Radzieckiej Republiki Łotwy, niemal dokładnie kopiującej konstytucję rosyjską z lipca 1918 r. ${ }^{16}$ Niemcy zdążyli jeszcze wyprzeć bolszewików z Rygi. Natomiast południe Łotwy pozostawało pod władzą sowiecką i zostało wyzwolone wspólnym uderzeniem (styczeń 1920 r.) wojsk łotewskich i polskich (generał E. Rydz-Śmigły) na rejon Dyneburga. Z rządem radzieckim najpierw (styczeń $1920 \mathrm{r}$.) zawarto rozejm, a następnie (sierpień 1920 r.) traktat pokojowy ${ }^{17}$. Łotwa obroniła niepodległość kosztem ogromnych strat ludzkich ${ }^{18}$ i materialnych.

Konstytucja przyjęta została 15 lutego 1922 r. Po upadku ZSRR i okresie przejściowym na Łotwie nastąpiło pełne przywrócenie mocy obowiązującej konstytucji z 1922 r. ${ }^{19}$

V. Kiedy wojna światowa wybuchła, myśląca cześć społeczeństwa litewskiego na ogół wiązała nadzieje narodowe z porażką Rosji i było to naturalne, skoro od ponad 100 lat przyszło im żyć pod rosyjską okupacją. Stąd też w mozaice politycznych orientacji na Litwie pewną przewagę miała opcja proniemiecka. Niemiecka ofensywa w lecie 1915 r. doprowadziła do okupacji niemal całej Litwy. Rewolucja lutowa 1917 r. i natychmiastowa liberalizacja systemu za czasów Rządu Tymczasowego wywołała ogromne ożywienie wśród mas litewskich. Powołano Radę ${ }^{20}$ (lit.: Taryba) z Antanasem Smetoną

12 Манифест Советского правительства Латвии, [w:] История советской конституичи. Сборник документов. 1917-1957 ..., s. 99-101.

13 История советской конституции. Сборник документов. 1917-1957 ..., s. 102.

${ }^{14}$ История советской конституции. Сборник документов. 1917-1957..., s. 102.

15 История советской конституции. Сборник документов. 1917-1957..., s. 103.

16 J. Zieliński, Parlament Łotwy, Warszawa 1997, s. 5.

${ }_{17}$ P. Kierończyk, w: Konstytucja Republiki Łotewskiej..., s. 10; WEP XVI, s. 303.

${ }^{18}$ Liczba mieszkańców zmniejszyła się z 2,5 mln do 1,6 mln; WEP XVI, s. 303.

19 P. Kierończyk, w: Konstytucja Republiki Łotewskiej..., s. 10-11, 25, passim; tamże tekst konstytucji w tłumaczeniu na język polski; J. Zieliński, op. cit., s. 6.

20 J. Ochmański, Historia Litwy, Wrocław-Warszawa-Kraków 1990, s. 267; WEP XVI, s. 72. 
jako przewodniczącym, która w dniu 11 grudnia 1917 r. proklamowała wznowienie niepodległego państwa litewskiego ze stolicą w Wilnie, zaś 11 listopada 1918 r. powołała pierwszy rząd litewski z Augustinasem Voldemarasem jako premierem. Kiedy jednak wojna zakończyła się porażką Niemiec i rozpadem Austro-Węgier oraz anulowaniem przez rząd radziecki separatystycznego pokoju brzeskiego, niezwłocznie bolszewicka Rosja ruszyła na zachód w swoim imperialistycznym pochodzie. Sowieci zastosowali swój powtarzany schemat, mający doprowadzić do opanowania kraju. Słabi komuniści litewscy ogłosili utworzenie władzy radzieckiej na Litwie, powołanie Tymczasowego Rewolucyjnego Rządu Robotniczo-Włościańskiego i proklamowali jego manifest $^{21}$. 22 grudnia 1918 r. - dokładnie według schematu zastosowanego w odniesieniu do Estonii i Łotwy - Rada Komisarzy Ludowych Rosji „na prośbę" litewskiej władzy radzieckiej uznała niezawisłość [независимость] Radzieckiej Republiki Litewskiej i jej rząd ${ }^{22}$. Jak już o tym była mowa w odniesieniu do Estonii i Łotwy, 25 grudnia 1918 r. Wszechrosyjski Centralny Komitet Wykonawczy potwierdził uznanie przez Radę Komisarzy Ludowych łącznie Estonii, Łotwy i Litwy ${ }^{23}$. Jak długo teren nie był opanowany przez regularną Armię Czerwoną, tak władza radziecka na terenach litewskich faktycznie nie istniała. Z Wilna ${ }^{24}$, kiedy tylko odeszło wojsko niemieckie, Taryba zbiegła do Kowna, zaś polskie jednostki samoobrony z łatwością rozgromiły (2 stycznia 1919 r.) sowiecką Wileńską Radę Robotniczą i opanowały miasto. Jednak już w 3 dni później nadciągnęły silne jednostki bojowe Armii Czerwonej i zdobyły Wilno.

Słabość komunistów zarówno na Litwie, jak i na Białorusi, skłoniła KC SDPRR(b) do podjęcia decyzji (1 stycznia 1919 r.) o połączeniu obu krajów i stworzenia jednej sowieckiej republiki litewsko-białoruskiej. Posłuszne rady delegatów w Mińsku oraz w Wilnie, pod ochroną Armii Czerwonej, głosowały jak im kazano i proklamowano (27 lutego 1919 r.) utworzenie Radzieckiej Socjalistycznej Republiki Litwy i Białorusi. Patriotyczne elity litewskie i białoruskie nie były w stanie stawić czoła Armii Czerwonej, oczywistej agresji czerwonej Rosji na Litwę i Białoruś. Jak wiadomo, z pomocą przyszła odbudowująca swoją państwowość Polska, której wojska w marcu i kwietniu 1919 r. szybką ofensywą (generał E. Śmigły-Rydz) opanowały Wileńszczyznę; na początku sierpnia 1919 r. wojsko polskie opanowało Mińsk. Władza sowiecka na Litwie i Białorusi przestała istnieć. Polskie rządy na Wileńszczyźnie Litwini potraktowali jako akt agresywny, jako polską okupację. Do

${ }^{21}$ История советской конституции. Сборник документов. 1917-1957..., s. 96-99.

22 История советской конституиии. Сборник документов. 1917-1957..., s. 102.

${ }^{23}$ История советской конституции. Сборник документов. 1917-1957..., s. 103; История советской конституции (в документах) 1917-1956..., s. 176-177.

${ }^{24}$ W 1917 r. Wilno liczyło ok. 139 tys. mieszkańców, w tym ok. 75 tys. Polaków (54\%), 57,7 tys. Żydów (41\%) i ok. 2,2 tys. Litwinów (1,6\%); WEP XXIX, s. 332. 
starć polsko-litewskich doszło na Suwalszczyźnie podczas opuszczania tego terenu przez wojska niemieckie.

VI. Zmagania między siłami patriotycznymi a siłami komunistycznymi na terenie byłego imperium carów najskromniej przedstawiają się na Białorusi, a to dlatego, że zarówno jedni, jak i drudzy byli na ziemiach białoruskich wyjątkowo słabi. W rezultacie Białoruś stała się głównie przedmiotem starć sił leżących poza ziemiami Białorusi i poza nurtami politycznymi płynącymi od Białorusinów. Jak wiadomo, w lecie 1915 r. ofensywa niemiecka opanowała nie tylko byłe Królestwo Polskie, lecz wojska niemieckie zajęły prawie całą Litwę (Kowno 18 sierpnia, Wilno 19 września), dużą część Łotwy, ważną linię kolejową Mińsk-Orsza, by w końcu roku ustabilizować linię frontu od Zatoki Ryskiej poprzez Baranowicze i Pińsk do granicy rumuńskiej. Wschodnia część ziem białoruskich znajdowała się jeszcze pod kontrolą wojsk carskich, ale panował tam chaos i gospodarka rabunkowa. Po rewolucji lutowej w Rosji Hromada zorganizowała (marzec 1917 r.) w Mińsku skromny zjazd organizacji narodowych. Przekazał on Rządowi Tymczasowemu oświadczenie domagające się stworzenia Rosji federacyjnej i przyznania Białorusi autonomii. Jesienią 1917 r. ukonstytuowała się Wielka Rada Białoruska (R. Pipes, s. 75-76). Aż do październikowego zamachu stanu 1917 r. o bolszewikach na ziemiach białoruskich niemal nie słychać. Obalenie Rządu Tymczasowego i wszczęcie już w grudniu 1917 r. przez Sowietów rozmów brzeskich w sprawie pokoju separatystycznego, nie przyniosły żadnych trwałych zmian. Po zawarciu traktatu brzeskiego (3 marca 1918 r.) i oddaniu przez Sowietów Mińska Niemcom nacjonaliści białoruscy usiłowali skorzystać z poparcia władz okupacyjnych i powołali (25 marca 1918 r.) rząd. Bez większego znaczenia, ponieważ krajem władali Niemcy. Sowieckie były oczywiście tereny wschodnie, poza linią demarkacyjną niemiecko-radziecką.

Po porażce Niemiec w I wojnie, ogłoszeniu anulowania przez sowietów separatystycznego pokoju brzeskiego oraz po ustąpieniu z Mińska wojsk niemieckich, białoruska sekcja w łonie SDPRR(b) poleciła proklamowanie (1 stycznia 1919 r.) Białoruskiej Socjalistycznej Republiki Radzieckiej ${ }^{25}$. Jak o tym była poprzednio mowa, 2-3 tygodnie wcześniej, w analogicznych okolicznościach, tego samego dokonano w Estonii, na Litwie i Łotwie. Schemat był ten sam. Bez zwłoki (3 lutego 1919 r.) I białoruski zjazd rad uchwalił deklarację o wszczęciu rozmów z RSFRR na temat wejścia BSRR w skład RSFRR na zasadach sfederowania ${ }^{26} \mathrm{i}$ - spieszył się bardzo - tegoż samego

${ }^{25}$ История советской конституции. Сборник документов. 1917-1957..., s. 103-106; История советской конституции (в документах) 1917-1956..., s. 177-181.

${ }^{26}$ Об установлении тесной федеративной связи между Советской Белоруссией и РСФСР, [w:] История советской конституции. Сборник документов. 1917-1957..., s. 109; История советской конституции (в документах) 1917-1956..., s. 185-186. 
dnia uchwalił konstytucję $\mathrm{BSRR}^{27}$, będącą ułomną, wielce niepełną $(1 / 3)^{28}$ kopią konstytucji rosyjskiej z 1918 roku. Proklamowano (27 lutego 1919 r.) utworzenie Radzieckiej Socjalistycznej Republiki Litwy i Białorusi. Jedynym ratunkiem tak dla Litwy, jak i Białorusi, zbyt słabych by się Armii Czerwonej skutecznie przeciwstawić, mogła być tylko pomoc z zewnątrz. I ona nadeszła: w kwietniu 1919 r. wojska polskie szybką ofensywą opanowały Wileńszczyznę; na początku sierpnia 1919 r. wojsko polskie zajęło Mińsk. Władza sowiecka na Litwie i Białorusi przestała istnieć.

Dalsza część białoruskiej historii należy do dużej wojny bolszewicko-polskiej z 1920 r. i zawartych po niej ustaleń pokojowych. Kiedy wojska radzieckie były pod Warszawą, zapadła w Moskwie decyzja i proklamowana została (1 sierpnia 1920 r.) Białoruska Socjalistyczna Republika Radziecka ${ }^{29}$.

Richard Pipes nie jest prawnikiem, toteż nie zajął się zagadnieniami prawnymi ustanowienia granicy polsko-białoruskiej/radzieckiej. Jak już kiedyś o tym pisałem ${ }^{30}$, w rozmowach pokojowych Rosji radzieckiej z Polską chodziło o przyszłość i granice nie Rosji sensu stricto, ale Ukrainy i Białorusi, przy czym Federacja Rosyjska oraz Ukraina ${ }^{31}$ występowały w rokowaniach samodzielnie i negocjowały układ na rzecz Białorusi. Białoruś w rokowaniach nie uczestniczyła ${ }^{32}$ i nie można twierdzić - jak czynią to niektóre źródła

27 История советской конститущии. Сборник документов. 1917-1957..., s. 110-113; История советской конституции (в документах) 1917-1956..., s. 187-190.

${ }^{28}$ Uzupełnienie ukazało się później: История советской конституции. Сборник документов. 1917-1957..., s. 136-141; История советской конституции (в документах) 1917-1956..., s. $251-257$.

29 История советской конституции. Сборник документов. 1917-1957..., s. 125-127; История советской конституции (в документах) 1917-1956..., s. 235-237.

30 A. Lityński, Prawo Rosji i ZSRR 1917-1991 czyli historia wszechzwiązkowego komunistycznego prawa (bolszewików), Warszawa 2012, s. 45-46.

31 Ukraińską Republikę Rad strona polska uznała już w październiku 1920 r. podczas zawierania umowy o preliminariach pokojowych i o rozejmie na 21 dni (zob. J. Kukułka, Traktaty sąsiedzkie Polski odrodzonej, Wrocław-Warszawa-Kraków 1998, s. 42). Strona polska wypowiedziała układ państwowy z Ukraińską Republiką Ludową i zerwała umowy wojskowe i polityczne z pozostałymi sojusznikami. Zob. J. Kumaniecki, Po traktacie ryskim. Stosunki polsko-radzieckie 1921-1923, Warszawa 1971, s. 36; Z. Karpus, Traktat ryski a polscy sojusznicy w okres wojny polsko-bolszewickiej 1920 roku, [w:] Traktat ryski 1921 roku po 75 latach. Studia, red. M. Wojciechowski, Toruń 1998, s. 236. Wprawdzie przedstawiciel URL Oleksiuk wraz z polską delegacją przez Gdańsk i Libawę dotarł do Rygi, ale nie uczestniczył w rokowaniach przy stole obrad. Strona polska nie była w stanie wymusić na delegacji sowieckiej zmiany jej stanowiska w kwestii ukraińskiej i jedynym reprezentantem społeczności ukraińskiej był przedstawiciel Ukrainy bolszewickiej (zob. Z. Karpus, op. cit., s. 238). Rząd URL wyznaczył swoją delegację, z S. Szełuchinem na czele, na konferencję pokojową. Delegacja ta przybyła do Rygi 3 października 1920 r., jeszcze przed podpisaniem preliminariów pokojowych i rozejmu, ale nie rozmawiano z nią. W sumie w Rydze przebywały 3 ukraińskie delegacje. Zob. E. Wiszka, Ukraińska Republika Ludowa wobec rozmów pokojowych i traktatu ryskiego 1921 roku, [w:] Traktat ryski..., s. 280, 286, passim.

32 Zob. m.in. O. Latyszonek, Biatoruskie elity polityczne wobec traktatu ryskiego, [w:] Traktat ryski..., s. 289 i n. 
rosyjskie ${ }^{33}$ - że Białoruś była reprezentowana przez Rosję. Białoruś nie była stroną traktatu.

VII. Richard Pipes w swojej książce Ukrainie poświęcił wiele miejsca, prezentując programy rozmaitych kierunków i idące za tym wydarzenia. Obraz jest bogaty, przeto tutaj wielce skomplikowanym problemom poświęcimy mniej miejsca.

Zaledwie car abdykował i dopiero co powstał Rząd Tymczasowy, a już 4(17) marca 1917 r. utworzono w Kijowie ukraińską Centralną Radę. Tak oto na powierzchnię życia politycznego na Ukrainie błyskawicznie wyszedł ruch narodowy, bazujący zresztą na politykach o dość zróżnicowanych opcjach społecznych. Bolszewicki zamach stanu w Piotrogrodzie wywołał aktywizację bolszewików na terenie całej Ukrainy. Wybuchły walki (7(20) listopada 1917 r.). Centralna Rada, w III uniwersale, proklamowała powstanie niezależnej Ukraińskiej Republiki Ludowej w federacyjnym związku z Rosją ${ }^{34}$. Centralna Rada postanowiła kontynuować udział w wojnie światowej, zaś państwa Ententy udzieliły jej pomocy. W szczególności ukraińska Centralna Rada wspierała Kozaków dońskich pod atamanem generałem Aleksym Kaledinem; ówcześnie była to główna siła białych. Państwa centralne w Brześciu m.in. zażądały, by Rada Komisarzy Ludowych uznała prawo Centralnej Rady do reprezentowania Ukrainy w czasie rokowań brzeskich; będąc w sytuacji przymusowej, RKL wyraziła taką zgodę ${ }^{35}$. Bolszewicy wszakże zawczasu nie zaniedbali zostawić sobie furtki: zjazdy SDPRR (b) w Kijowie oraz w Charkowie (grudzień 1917 r.) opowiedziały się za utworzeniem Ukraińskiej Republiki Rad i już 14 (27) grudnia 1917 r. w Charkowie nastąpiło utworzenie Sekretariatu Ludowego Ukraińskiej Republiki Robotniczo-Chłopskiej - pierwszego rządu radzieckiej Ukrainy ${ }^{36}$. W opanowanym przez czerwonych Kijowie zainstalował się rząd Ukrainy radzieckiej. Centralna Rada ewakuowała się do Żytomierza, później do Sarn, ale 9(22) stycznia 1918 r. proklamowała niezależnym i suwerennym państwem Ukraińską Republikę Ludową. URL została uznana przez państwa centralne, a 9 lutego 1918 r. zawarła z nimi traktat pokojowy. Podpisany w końcu przez Sowietów traktat brzeski (3 marca 1918 r.) zawierał postanowienie o opuszczeniu przez wojska czerwonej Rosji terenów Ukrainy oraz o uznaniu traktatu pokojowego między Centralną Radą a państwami centralnymi. Udzielając pomocy Centralnej

${ }^{33}$ История отечественного государства и права, ч. 2, ред. О.И. Чистяков, Москва 2006, s. 155 .

34 W. Serczyk, Historia Ukrainy..., s. 260; zob. też E. Toczek, wstęp do: Konstytucja Ukrainy uchwalona na piątej sesji Rady Najwyższej Ukrainy 28 czerwca 1996 roku, wstęp i tłum. E. Toczek, Warszawa 1999, s. 7.

35 W. Serczyk, op. cit., s. 265.

36 Zob. też История советской конституции. Сборник документов. 1917-1957..., s. 33-34. 
Radzie, Niemcy wprowadzili na Ukrainę półmilionową armię. Rozpętała się krwawa wojna domowa z siłami ukraińskich bolszewików oraz przybyłymi z Rosji czerwonogwardzistami. Pojawił się nowy ośrodek władzy: na zjeździe partii chłopskiej gen. Paweł Skoropadski okrzyknięty został (29 kwietnia 1918 r.) „hetmanem Ukrainy”. Sam ogłosił się jedynowładcą nowego państwa ukraińskiego. Po porażce Niemiec w wojnie światowej kolejnym ośrodkiem władzy próbował zostać (14 listopada 1918 r.) pięcioosobowy Dyrektoriat, który powołał rząd i siły zbrojne - Strzelców Siczowych pod komendami Eugeniusza Konowalca i Andrzeja Melnyka. Skoropadski zbiegł do Niemiec. Rosły siły ukraińskich bolszewików, którzy realizowali reformy społeczne ${ }^{37}$.

W przeciwieństwie do Richarda Pipesa, my w Polsce dobrze pamiętamy o pojawieniu się na ziemiach ukraińskich jeszcze jednego ośrodka władzy. Ukraińcy z terenów byłego zaboru austriackiego w październiku 1918 r. proklamowali Zachodnioukraińską Republikę Ludową. Natychmiast znalazła się ona w stanie wojny z Polską. Walczyły z nią także siły radzieckie.

Ofiarowanie przez Stany Zjednoczone sprzętu wojskowego nie zatrzymało ofensywy Armii Czerwonej i sił bolszewickich na Ukrainie; padł Charków. Czerwoni proklamowali (6 stycznia $1919 \mathrm{r}^{38}$ ) zmianę nazwy państwa na: Ukraińska Socjalistyczna Republika Radziecka. Tymczasowy Rząd Robotniczo-Chłopski przekształcony został (29 stycznia 1919 r.) w Radę Komisarzy Ludowych USRR. Zapowiedziano federację z RSFRR ${ }^{39}$. „Rok 1919 był na Ukrainie czasem zupełnej anarchii. Terytorium kraju rozpadło się na wiele obszarów oddzielonych od siebie i reszty świata" - napisał Richard Pipes (s. 139) i są to słowa bardzo trafnie sumujące obraz rzeczywistości. Ukraina radziecka otrzymała (10-14 marca 1919 r.) konstytucję ${ }^{40}$. Konstytucja była wierną kopią rosyjskiej z 1918 r., ale stanowiła, że USRR ma prawo prowadzenia własnej polityki zagranicznej. W kwietniu 1919 r. Armia Czerwona dotarła do Zbrucza.

Druga połowa r. 1919 zapowiadała się jako koniec władzy radzieckiej w całej dawnej Rosji. Od wiosny z rejonu północnego Kaukazu niepowstrzymanie szła przez Ukrainę na Moskwę Armia Ochotnicza Denikina. Na północy - z terytorium Estonii - ofensywę rozpoczął Judenicz. Zza Uralu atakował Kołczak. Poważnym zagrożeniem dla obu stron były duże siły atamana Nestora Machny. Dla bolszewików nie byłoby ratunku, ale - jak wiadomo

37 Zob. История советской конституции. Сборник документов. 1917-1957..., s. 93; История советской конституц̧ии (в документах) 1917-1956..., s. 167-168.

38 Charków został stolicą Ukrainy do $1934 \mathrm{r}$.

39 Zob. История советской конституции. Сборник документов. 1917-1957..., s. 106-107; История советской конституциии (в документах) 1917-1956..., s. 181-183.

40 История советской конституции. Сборник документов. 1917-1957..., s. 113-118; История советской конститузции (в документах) 1917-1956..., s. 192-198. W oficjalnych dokumentach data konstytucji tak właśnie jest zapisana: 10-14 marca. 
- wszyscy biali generałowie szli z hasłami odbudowy dawnej niepodzielnej, nieuszczuplonej Rosji, bez koncesji na rzecz narodów. Wszak dlatego Piłsudski nie podjął współpracy wojskowej z Denikinem. Zaślepienie Denikina wydaje się być absolutnie skrajne.

Petlura podjął ostatnią próbę ratowania Ukrainy, wiążąc się z Polską (kwiecień 1920 r.). Wojna bolszewicko-polska była ostatnią wówczas próbą wyrwania bolszewikom fragmentu dawnej Rosji. Koniec tej wojny był końcem wojny domowej w europejskiej części Rosji.

VIII. Zróżnicowanie etniczne, kulturowe, religijne, doświadczenia historyczne w sposób naturalny skutkowały rozmaitością ruchów narodowych na Zakaukaziu. Dramatyczna dla Ormian konfrontacja z Turcją ${ }^{41}$ (a także z tureckojęzyczną ludnością azerską) musiała powodować, że zwracali oni wzrok w kierunku Rosji, zwłaszcza w latach wojen bałkańskich. Pierwsza wojna światowa to dość długo w zakaukaskiej optyce była wojna rosyjsko-turecka, a na tym froncie, aż do 1917 roku włącznie, Rosja odnosiła sukcesy, zupełnie inaczej aniżeli w Europie. Upadek caratu i działalność Rządu Tymczasowego skutkowały najpierw reorganizacjami natury administracyjnej. Rząd Tymczasowy uznał autonomię narodów kaukaskich.

Zarzewie konfliktów narodowościowych oraz społecznych rozpaliło się zanim jeszcze w Piotrogrodzie doszło do bolszewickiego przewrotu. Po zamachu stanu bolszewików konflikt musiał więc tylko eskalować. Najpierw (15/28 listopada 1917 r.) dasznacy ${ }^{42}$ (Ormianie) wraz z mienszewikami (Gruzini) i Musywatystami (Azerowie) utworzyli pełniący rolę rządu tymczasowego Zakaukaski Komisariat, a nieco później (23 lutego 1918 r.) te 3 siły, wsparte socjalistami i kadetami ${ }^{43}$, zwołały zakaukaski sejm narodowościowy. Kiedy

${ }^{41}$ Armenię Turcy osmańscy zajęli w końcu XIV w. Na początku czasów nowożytnych (XVI-XVII stulecia) ziemie zamieszkałe przez Ormian, a także Azerów, stały się przedmiotem zbrojnej rywalizacji między Turcją a Persją, a w rezultacie zachodnią Armenię opanowała Turcja, zaś wschodnią Persja. Wojny i okupacje przez dziesięciolecia powodowały migracje Ormian, także do Indii i na Daleki Wschód. Po wojnach Rosji z Persją (1828) do państwa carów przyłączona została wschodnia Armenia, zaś po wojnie z Turcją (1877-1878) część północna. Na losach narodowych Ormian trwale zaciążył jednak fakt, iż znaczna ich część mieszkała w rozproszeniu we wschodniej Anatolii, we wrogim im państwie i wrogiej społeczności tureckiej, zaś ludobójstwo tureckie z końca XIX w. (mniej znane społeczności międzynarodowej) i z 1915 r. nie mogło pozostać bez znaczenia dla stosunku Ormian do państwa rosyjskiego.

42 Dasznacy: ormiańska partia narodowa (Dasznakcutjun - sojusz), założona w 1890 r. w Tyflisie (Tbilisi). Początkowo opowiadała się za autonomią ormiańską w Turcji. Po rewolucji październikowej w Rosji opowiedziała się za oderwaniem Armenii od Rosji.

${ }^{43}$ Kadeci (od KD - konstytucyjni demokraci) - Partia Konstytucyjno-Demokratyczna, od 1906 r. Partia Wolności Ludu; utworzona w październiku 1905 r., skupiała głównie inteligencję i liberalną szlachtę, w programie miała wprowadzenie w Rosji monarchii konstytucyjnej, po $1917 \mathrm{r}$. opowiedzieli się za ustrojem republikańskim, początkowo stanowili główną siłę Rządu Tymczasowego, przeciwnicy bolszewików; bolszewicy ogłosili ich partią kontrrewolucyjną, partią wrogów ludu i nakazali aresztowania. O dekrecie Rady Komisarzy Ludowych w sprawie kadetów zob. 
bolszewicy niemal na kolanach podpisali traktat brzeski (3 marca 1918 r.), odrywający od Rosji ważną część Zakaukazia (Batumi, Kars), zakaukaski sejm narodowościowy ogłosił (22 kwietnia 1918 r.) Zakaukazie niezależną od Rosji demokratyczną republiką. Opuszczenie Rosji przez wszystkie kraje Zakaukazia i utworzenie Republiki Zakaukaskiej zbiegło się ze skuteczną wielką ofensywą turecką oraz zbliżaniem się - po traktacie brzeskim - wojsk niemieckich. Zapanował chaos polityczny; podjęto próby porozumienia z Turcją, ale bezskutecznie. Tureckie żądania terytorialne były nie do przyjęcia: Gruzja miała być okrojona do minimum, a Armenia miała niemal zniknąć z mapy. Rozbieżne interesy narodowe i rozmaite widzenie drogi do uratowania niepodległości spowodowały rozpad federacyjnej Republiki Zakaukaskiej już w miesiąc po jej powstaniu.

Kiedy podpisany został pokój kończący udział Turcji w I wojnie światowej i określający jej wschodnią granicę na Zakaukaziu ${ }^{44}$, w listopadzie 1920 r. ormiańscy bolszewicy wzniecili powstanie, wezwali na pomoc Armię Czerwoną, która po ciężkich, wielomiesięcznych walkach obaliła rządy dasznaków. Armenia była całkowicie wyniszczona i wygłodzona; na skutek mordów tureckich i azerskich wielce ucierpiała ludność, masowe było sieroctwo dzieci i bezdomność. Trzeba przyznać, że Rosja udzieliła Armenii pomocy żywnościowej. Na początku 1921 r. pozostający w konspiracji dasznacy wywołali ogólnonarodowe powstanie antybolszewickie; zdobyli (18 lutego 1921 r.) Erewań, panowali nad sytuacją. Na wiosnę przybyły z Rosji dodatkowe wojskowe siły i Armia Czerwona do początków lipca stłumiła powstanie. Na zjeździe rad Armenii (styczeń 1922 r.) wyrażono wdzięczność Rosji Radzieckiej i jej armii, które przyniosły zwycięstwo rewolucji i przyjęto konstytucję na wzorach rosyjskich ${ }^{45}$.

Wcześniej w Azerbejdżanie, zwłaszcza w uprzemysłowionym i proletariackim Baku, zaraz po piotrogrodzkim przewrocie bolszewickim (31 października/9 listopada 1917 r.), bakińska rada proklamowała ustanowienie władzy radzieckiej. W marcu 1918 r. musawatyści zorganizowali antybolszewickie powstanie i Narodowy Kongres Azerbejdżanu proklamował (maj 1918 r.) utworzenie Demokratycznej Republiki Azerbejdżanu. Walki z siłami bolszewickimi były długie i krwawe aż do wkroczenia Armii Czerwonej, która obaliła władze niepodległej Republiki; ogłoszono wówczas (w Baku 28 kwietnia 1920 r.) utworzenie Azerbejdżańskiej Socjalistycznej Republiki

W. Lenin, Dzieła wszystkie, t. 35, Warszawa 1988, s. 134. Leksykon historii świata: Rosja, red. W. Sienkiewicz, Warszawa 2001, s. 139.

44 Jak wiadomo, traktat w Sẻvres z 10 sierpnia 1920 r. nie został wykonany. Turcja zaś już we wrześniu 1920 r. najechała Armenię, a zawarty po tej wojnie pokój armeńsko-turecki dawał Turcji znaczne nabytki terytorialne, m.in. granicę z Gruzją.

45 История советской конституции. Сборник документов. 1917-1957.., s. 163-172; История советской конституции (в документах) 1917-1956..., s. 321-333. 
Radzieckiej. Na zjeździe rad w Baku, 19 maja 1921 r., przyjęto konstytucję Azerbejdżańskiej Socjalistycznej Republiki Radzieckiej ${ }^{46}$.

W Gruzji, po rozpadzie federacyjnej Republiki Zakaukaskiej, mienszewicy gruzińscy powołali (26 maja 1918 r.) Demokratyczną Republikę Gruzińską i rozpaczliwie poszukując ratunku, entuzjastycznie przyjęli niemiecką obietnicę opieki (faktycznie protektoratu). Od początku 1919 r. dochodziło do starć między siłami gruzińskimi oraz siłami stacjonującego wówczas na Północnym Kaukazie generała Denikina; w poważniejszym zakresie walki rozgorzały w Abchazji (luty 1919 r.). Anglicy próbowali nakłonić Gruzinów do współdziałania z białą armią Denikina, ale ten nie po raz pierwszy i nie po raz ostatni ujawnił swój rosyjski nacjonalizm, a nawet imperializm i nie ukrywał, że ma zamiar odbudować imperium rosyjskie $w$ dawnych granicach, a więc z Gruzją jako jego prowincją.

Kolejna rewolta bolszewików, wspomaganych siłami czerwonych z Armenii oraz regularnymi jednostkami sił zbrojnych przysłanymi z Rosji, dała czerwonym panowanie nad większością terenów Gruzji, w tym nad stolicą Tbilisi (25 lutego 1921 r.). Nie pierwszy i nie ostatni to przypadek, gdy rywalizacja między sobą (nawet wojna) nie pozwalała na współdziałanie krajów przeciwko bolszewikom, a tym ostatnim pozwoliła zdobywać każdy kraj z osobna.

Dnia 21 maja 1921 r. Radziecka Socjalistyczna Republika Gruzji zawiązała z RSFRR wojskowy i państwowy „związek” [военный и хозяйственный союз $]^{47}$. W dniu 28 lutego 1922 r. na gruzińskim zjeździe rad przyjęto konstytucję Socjalistycznej Radzieckiej Republiki Gruzji ${ }^{48}$, która - na papierze - deklarowała suwerenność państwową Gruzji ${ }^{49}$, zaś zasady, struktura władz oraz klasowe cele wzorowane były na konstytucji rosyjskiej.

W żadnym z zakaukaskich krajów bolszewicy nie doszli do władzy legalnie, ani nawet siłami lokalnymi; wszędzie stało się to przy pomocy przysłanej z głębi Rosji Armii Czerwonej, która orężem zdławiła siły narodowe i pragnienia utworzenia niepodległego państwa. Kaukaski model zdobyczy terytorialnych Sowietów polegał m.in. na opanowywaniu jednego kraju, by stał się on przyczółkiem do opanowywania następnego.

Dalsze losy narodów Zakaukazia pod panowaniem rosyjskim przez następnych 70 lat potoczyły się w miarę typowo. Na zjeździe przedstawicieli komitetów wykonawczych rad (niski to szczebel w hierarchii ustrojowej) re-

46 История советской конституции. Сборник документов. 1917-1957..., s. 149-161; История советской конституциии (в документах) 1917-1956..., s. 284-299.

47 История советской конституции. Сборник документов. 1917-1957..., s. 161-162; История советской конституциии (в документах) 1917-1956..., s. 299-300.

48 История советской конституции. Сборник документов. 1917-1957..., s. 174-189; История советской конституичии (в документах) 1917-1956..., s. 339-357.

49 Analizę konstytucji Gruzji pod kątem stosunku Gruzji do federacji państw socjalistycznych przeprowadził W. Suchecki, Geneza federalizmu radzieckiego, Warszawa 1961, s. 224-225. 
publik Armenii, Gruzji i Azerbejdżanu, wbrew miejscowym bolszewikom ${ }^{50}$, 12 marca 1922 r. utworzono Związek Socjalistycznych Radzieckich Republik Zakaukazia $^{51}$. Wobec zadecydowanego już przez partię komunistyczną utworzenia ZSRR, 13 grudnia 1922 r. na zakaukaskim zjeździe rad przyjęto konstytucję tego związku i jednocześnie nadano mu nazwę wyraźniej odróżniającą od tworzonego ZSRR: wysunięto na plan pierwszy geograficzne położenie federacji, czego z premedytacją unikano w nazwie ZSRR. Nazwa radzieckiego Zakaukazia odtąd brzmiała: Zakaukaska Socjalistyczna Federacyjna Radziecka Republika ${ }^{52}$. Wprowadzona w życie w 1936 r. konstytucja tzw. stalinowska nie przewidywała już istnienia Federacyjnej Republiki Zakaukaskiej i wymieniała (art. 13) wszystkie 3 republiki na równi z innymi, a łącznie było ich wówczas $11^{53}$.

Kaukaz Północny to teren narodowościowo wielce zróżnicowany. W skomplikowanej sytuacji klasowej i społecznej lokalne walki rozpoczęły się wkrótce po rewolucji październikowej i trwały 3 lata. W końcu bolszewicy teren opanowali i utworzyli dwie republiki: Dagestańską Autonomiczną Socjalistyczną Republikę Radziecką (1920 r.) oraz Republikę Górską ${ }^{54}$.

IX. W byłym imperium carów Kozacy ${ }^{55}$ liczyli około 4,5 mln osób, przy czym 300 tysięcy z nich walczyło w I wojnie światowej; tradycyjnie ludność kozacka trudniła się służbą wojskową. Łącznie trzynaście regionów („wojsk”) kozackich miało bronić imperium; część była położona daleko od centrum i ognisk rewolucyjnych; stanice na Syberii nie mogły zagrozić stolicy. W czasach carskich cieszyli się przywilejami, m.in. mieli prawo tworzenia lokalnych samorządów. W rezultacie byli mniej podatni na hasła rewolucyjne.

Na wieść o obaleniu Rządu Tymczasowego w bolszewickim zamachu stanu najszybciej (26 października/8 listopada 1917 r.) w całym byłym imperium zareagowali właśnie Kozacy - negatywnie. Kozacy dońscy pod atamanem generałem Aleksym Kaledinem ${ }^{56}$, Kozacy orenburscy pod atamanem pułkow-

50 Niesnaski wewnątrz partii komunistycznej na ten temat omówił R. Pipes, s. 266-272.

51 История советской конституции. Сборник документов. 1917-1957..., s. 189-190; История советской конституц̧ии (в документах) 1917-1956..., s. 358-360.

52 История советской конституции (в документах) 1917-1956.., s. 374-383; История советской конституции. Сборник документов. 1917-1957..., s. 195-202.

53 История советской конституции. Сборник документов. 1917-1957..., s. 347; История советской конституции (в документах) 1917-1956..., s. 730.

54 E. Mawdsley, Wojna domowa w Rosji 1917-1920, thum. M. Popławska, Warszawa 2010, s. 283; zob. też W. Suchecki, op. cit., s. 119, 207.

55 Główną część fragmentu dot. Kozaków europejskich publikowałem pod tytułem Rewolucji rosyjskiej rok pierwszy. Wybrane zagadnienia prawa karnego, [w:] Nil nisi veritas. Księga dedykowana Profesorowi Jackowi Matuszewskiemu, Łódź 2016 [w chwili pisania niniejszego tekstu - w druku].

56 Aleksiej M. Kaledin (1861-1918), generał, podczas I wojny światowej dowódca korpusu i armii; w czerwcu 1917 r. wybrany atamanem kozackiego Wojska Dońskiego; po klęsce w walkach z bolszewikami popełnił samobójstwo. Leksykon historii świata ..., s. 121. 
nikiem Aleksandrem Dutowem, Kozacy zabajkalscy pod esaułem Grigorijem Siemionowem - wszyscy oni natychmiast po otrzymaniu wieści o bolszewickim zamachu odmówili podporządkowania się nowym w stolicy kraju władzom $^{57}$.

Zbrojnie szybko wystąpił ataman Dutow, a stanica orenburska - położona tam gdzie Europa styka się z Syberią i Azją Środkową - stała się niezwłocznie aktywnym, a tak daleko położonym ośrodkiem walki z siłami bolszewickimi. Dutow obalił radę w Orenburgu i przez jakiś czas rozszerzał teren swoich wpływów. Nie długo jednak. Wracający z frontu żołnierze kozaccy nie mieli ochoty do dalszego wojowania, a często byli zarażeni hasłami i praktyką nieposłuszeństwa wobec władzy, także wojskowej. Nękały Dutowa oddziały zbolszewizowanych robotników, wysyłane często z daleka w trybie ,wojny eszelonowej”, a w końcu nie dał rady Północnej Lotnej Kolumnie wojsk bolszewickich; Orenburg został przez nich zdobyty (31 stycznia 1918 r.), a sam ataman z małą już garstką wiernych żołnierzy zepchnięty został na tereny południowego Uralu, a wiosną 1918 r. na stepy kazachskie ${ }^{58}$.

Czwartą co do wielkości stanicą kozacką w Rosji była Stanica Zabajkalska. Usytuowana była w ważnym strategicznie miejscu, bo na wschód od Bajkału, ale także na zachód od zbiegających się (rozchodzących się) tam 2 wielkich magistrali kolejowych: Kolei Transsyberyjskiej i Kolei Wschodniochińskiej (zob. niżej). Panowanie nad tymi kolejami to było panowanie nad Dalekim Wschodem i to nie tylko Rosji, lecz także nad częścią Chin. Przywódcą Kozaków Zabajkalskich był wspomniany Grigorij Siemionow. W końcowym okresie swoich bojów i swojego życia, 4 stycznia 1920 r., Kołczak przekazał Siemionowowi pełnię władzy wojskowej i cywilnej na Syberii ${ }^{59}$. Kozacy Zabajkalscy, podobnie jak i inni z Dalekiego Wschodu, znakomicie zrażali sobie ludność miejscową okrutnym i ślepym terrorem, mordami, rabunkami, bezlitosnymi rekwizycjami. Dotyczy to tak Siemionowa, jak i w szczególności Iwana Kałmykowa, atamana Kozaków Ussuryjskich. Przy ich poczynaniach terror czerwonych wydawał się być łagodny ${ }^{60}$. Inne stanice syberyjskie były mniej liczne.

Najważniejszy był jednak kozacki obwód wojska dońskiego. Liczba tamtejszych Kozaków sięgała ponad 1,5 mln. Terytorium wojska dońskiego to była Europa i położenie było strategiczne: blisko Ukrainy i zagłębia węglowego Donbas, zaś największe miasta nad Donem - kozacka stolica regionu Nowoczerkask oraz Rostów - leżały na szlaku kolejowym łączącym Rosję

${ }^{57}$ R. Wojna, W ogniu rosyjskiej wojny wewnętrznej 1918-1920, Warszawa 1975, s. 28-29; zob. też E. Mawdsley, op. cit., s. 36-38.

${ }^{58}$ E. Mawdsley, op. cit., s. 32-37.

59 R. Dyboski, Siedem lat w Rosji i na Syberii (1915-1921). Przygody i wrażenia, oprac. T. Bohun, Warszawa 2007, s. 99.

${ }^{60}$ Ibidem, s. 96-103, passim; zob. też E. Mawdsley, op. cit., s. 187. 
z Kaukazem. Na zaproszenie atamana generała Aleksego Kaledina do Nowoczerkaska ściągali politycy i wojskowi wobec bolszewików opozycyjni. Przybyli m.in. generał Anton Iwanowicz Denikin ${ }^{61}$, generał Ławr Gieorgijewicz Korniłow $^{62}$, najsłynniejszy były terrorysta pierwszej połowy XX w., Borys Wiktorowicz Sawinkow ${ }^{63}$. To tam rozpoczęła się organizacja „Armii Ochot-

${ }^{61}$ Anton Iwanowicz Denikin, ur. 1872 w Łowiczu, gdzie ojciec oficer carski odbywał służbę, z matki Polki. Ukończył Akademię Sztabu Generalnego; uczestnik wojny rosyjsko-japońskiej; generał od czerwca 1914; w czasie I wojny światowej dowodził dywizją, korpusem; po rewolucji lutowej 1917 szef sztabu naczelnego wodza (maj-czerwiec); m.in. dowódca frontu zachodniego; za poparcie planowanego zamachu stanu Korniłowa aresztowany; po rewolucji październikowej zbiegł nad Don (grudzień 1917), gdzie współorganizował Armię Ochotniczą; po śmierci gen. Korniłowa (kwiecień 1918) objął dowództwo nad Armią Ochotniczą; podporządkował sobie Kozaków; od 1919 stanął na czele Sił Zbrojnych Południa Rosji (Armia Ochotnicza, Dońska, Kaukaska); podczas ofensywy A. Kołczaka na Ural D. zajął Zagłębie Donieckie i Ukrainę, a we wrześniu 1919 rozpoczął ofensywę na Moskwę zajmując m.in. Kurs i Orzeł. Dobry wojskowy, ale fatalny jako polityk, popełniał kardynalne błędy: wszędzie szedł z hasłami przywrócenia Rosji imperialnej, w niezmienionych granicach, czym robił sobie wrogów z sił narodowych (np. na Kaukazie, Ukraińców, Polaków), wszędzie też anulował bolszewicki dekret o ziemi, czym wrogo nastawiał chłopów. Rozbity pod Orłem wrócił na Krym; 1920 oddał dowództwo w ręce Wrangla. Wyjechał do Konstantynopola, Francji, a stamtąd - w obawie deportacji - do USA (1945). Pozostawił obszerne wspomnienia i analizy, WEP VII; s. 84; G. Przebinda, J. Smaga, Kto jest kim w Rosji po 1917 roku. Kraków 2000, s. 66; Leksykon historii świata ..., s. 67.

62 Ławr Gieorgijewicz Korniłow (1870-1918), urodził się koło Karagandy (Kazachstan) jako syn oficera, pochodził z rodziny kozackiej, absolwent szkoły artylerii i Akademii Sztabu Generalnego, znał języki turecki, perski, chiński; uczestnik wojny rosyjsko-japońskiej (1904-1905); attaché wojskowy w Chinach; w czasie I wojny dowódca dywizji, potem korpusu; ranny trafił do niewoli austriackiej, z której brawurowo uciekł, co przydało mu popularności; po rewolucji lutowej dowódca piotrogrodzkiego okręgu wojskowego, odpowiedzialny za ochronę rodziny byłego cara; 19 lipca (1 sierpnia) 1917 r. mianowany naczelnym wodzem całości sił rosyjskich; w czasie ofensywy w czerwcu 1917 w obliczu panicznej ucieczki całych oddziałów rosyjskich zażądał przywrócenia przez rząd kary śmierci na froncie, co uzyskał; jako jedyny z carskich generałów prezentował poglądy demokratyczne, co wydawało się do zaakceptowania dla Rządu Tymczasowego i w jakimś porozumieniu z Kiereńskim, w celu „opanowania w Rosji anarchii”, wysłał siły wojskowe dla spacyfikowania stolicy z jej zdemoralizowanym dużym garnizonem, ale premier rządu wycofał się z ustaleń i pucz się nie udał, zaś Korniłow został na polecenie rządu aresztowany; po zamachu bolszewickim zbiegł (grudzień 1917) z aresztu i udał się nad Don; był jednym z organizatorów i głównodowodzącym Armii Ochotniczej na południu Rosji, głównej wojskowej formacji białych; zginął w czasie szturmu na Jekatierinodar. J. Smaga, w: G. Przebinda, J. Smaga, Kto jest kim ...; Leksykon historii świata: Rosja...; Wielka Encyklopedia Powszechna [WEP]; A. Kijas, [w:] Leksykon historii powszechnej 1900-1945, red. S. Sierpowski przy współpracy S. Żerki, Poznań 1996; P. Wieczorkiewicz, w: L. Bazylow, Historia Rosji, Wrocław-Warszawa-Kraków 2005, s. 382.

${ }^{63}$ Borys Wiktorowicz Sawinkow (1879-1925), urodził się w Charkowie w rodzinie prokuratora wojskowego, po 1881 ojciec jego przeniesiony został do Warszawy na stanowisko sędziego; Borys uczył się w Warszawie, studiował kulturę i historię Polski, mówił dobrze po polsku; nawiązał kontakty z Polską Partią Socjalistyczną; studia rozpoczął na wydziale prawa uniwersytetu w Petersburgu, po dwóch latach relegowany za działalność polityczną (poparł studentów Warszawy protestujących przeciwko odsłonięciu pomnika Michaiła Murawjowa-Wieszatiela); studia kontynuował w Berlinie i Heidelbergu; wykształcony, inteligentny, o wybitnych zdolnościach organizacyjnych; 1900 wrócił do Rosji; pisał o konieczności wykształcenia zawodowej elity rewolucjonistów; 1903 zbiegł za granicę i w Genewie poznał Jewno Azefa, który w tym czasie stanął na czele Wydziału 
niczej”, która pod dowództwem Denikina miała największe szanse obalenia władzy Sowietów.

X. Na ogromnych obszarach, na wschód od Wołgi aż do brzegów Pacyfiku, do wiosny 1918 r. władza sowietów teoretycznie miała się dobrze, mimo że w wyborach do konstytuanty bolszewicy zdobyli tylko $10 \%$ głosów na Syberii i $20 \%$ na Uralu ${ }^{64}$. Panowanie nad takim gigantycznym obszarem zależało oczywiście przede wszystkim od panowania nad Koleją Transsyberyjską $^{65}$. Tu na przeszkodzie stanął znany, ale rozmaicie komentowany, bunt

Bojowego Partii Socjalistów-Rewolucjonistów [S-R; eserowcy] (a który - jak się później 1908 okazało - był jednocześnie agentem Ochrany); wspólnie z Azefem dokonał zamachu na ministra spraw wewnętrznych Wiaczesława Plehwego (zabity 1904), uczestniczył w zamachach na wielkiego księcia Sergiusza - generała-gubernatora Moskwy i popa Georgija Gapona (zabici w 1905-1906) i inne; aresztowany 1906 przy nieudanym zamachu zbiegł z więzienia za granicę; za granicą napisał główne książki swojego życia dot. psychologii terroryzmu, a także autobiograficzne, w których m.in. wyraził rozczarowanie słabymi skutkami terroru politycznego; 1914-1917 służył jako ochotnik w armii francuskiej; po rewolucji lutowej wrócił do Rosji i przez Kiereńskiego został mianowany komisarzem Rządu Tymczasowego przy Kwaterze Głównej i od IX 1917 ministrem wojny; popierał Korniłowa w czasie podjętej przez niego próby zamachu stanu; w kołach politycznych Piotrogrodu mówiło się o planowanej kolektywnej dyktaturze Kornikowa, Sawinkowa i Kiereńskiego; po upadku puczu Korniłowa został usunięty z Partii S-R. Po rewolucji październikowej stanął na czele antybolszewickiego Związku Obrony Ojczyzny i Wolności, przygotowywał zamachy na Lenina i Trockiego, agitował wśród chłopów na prowincji; na początku 1918 uczestniczył w tworzeniu Armii Ochotniczej na Kubaniu, pod nadzorem Kornikowa, a następnie Denikina; w VII 1918 po wybuchu w Moskwie powstania lewicowych eserowców zorganizował antybolszewickie powstania w Jarosławiu nad Wołgą, Muromiu i Rybińsku, zaś po ich zdławieniu i wprowadzeniu przez bolszewików czerwonego terroru organizował grupy terrorystyczne i kierował licznymi akcjami dywersyjnymi; przez Japonię wyemigrował (1919) do Europy, gdzie organizował pomoc dla Kołczaka i Denikina.

W 1920 przybył do Warszawy i w kontakcie z Józefem Piłsudskim organizował działalność antybolszewicką; współpracował z organizatorem białej partyzantki na Białorusi - Stanisławem Bułak-Bałachowiczem; w 1921 zmuszony do wyjazdu z Polski na skutek noty protestacyjnej rządu radzieckiego; od 1921 w Paryżu, poszukiwał pomocy u Mussoliniego. Agentom OGPU (bezpieki) udało się zwabić go do potajemnego przybycia do ZSRR 16/17 VIII 1924 celem rzekomego objęcia przywództwa konspiracyjnej opozycji; aresztowany VIII 1924 w Mińsku; przebywał na Łubiance; złamany w śledztwie zeznawał na procesie zgodnie $\mathrm{z}$ instrukcjami bezpieki; sąd pod przewodnictwem Wasilija Ulricha skazał go na karę śmierci, zamienioną ,za zasługi w walce z caratem" na 10 lat pozbawienia wolności; 17 V 1925 według wersji oficjalnej popełnił samobójstwo: „na oczach strażników wypadł” z okna V piętra na Łubiance, prawie na pewno został wyrzucony przez czekistów. M. Smoleń, w: Encyklopedia białych plam, t. XVI, Radom 2005; G. Przebinda, [w:] G. Przebinda, J. Smaga, Kto jest kim ...; Leksykon historii świata...; A. Kijas, [w:] Leksykon historii powszechnej; B. Urbankowski, Józef Pitsudski - marzyciel i strateg. Poznań 2014; A.S. Kowalczyk, Sawinkow, Warszawa 1992.

${ }^{64}$ E. Mawdsley, op. cit., s. 135.

65 Transsyberyjska Kolej, Transsyberyjska Magistrala, Wielka Magistrala Syberyjska: jedna z najdłuższych na świecie linii kolejowych, łączy europejską część Rosji z Syberią i Dalekim Wschodem; zbudowana w latach 1895-1916; długość 9332 km, nie licząc odgałęzień; biegnie z Moskwy przez Omsk, Irkuck, Chabarowsk do Władywostoku; dwutorowa; z odgałęzieniem do Mongolii i Chin; obecnie zelektryfikowana; WEP XXVII, s. 569; Leksykon historii świata ..., s. 264. 
Korpusu Czechosłowackiego ${ }^{66}$. Wielce skrótowo tylko sygnalizując, trzeba przypomnieć, że powstawały ośrodki władzy białych, m.in. w Samarze nad Wołgą, w Omsku, w Ufie, zaś w nocy 17 na 18 listopada 1918 r. utworzono pięcioosobowy Dyrektoriat, a na jego prośbę głową państwa został, i tytuł Wielkorządcy Rosji zgodził się przyjąć admirał Aleksander Wasiljewicz Kołczak $^{67}$. W ten sposób powołano dyktaturę wojskową. Jak wiadomo, siły zbrojne Kołczaka - jak długo odnosiły sukcesy - rozwijały ofensywę w zasadzie wzdłuż kolei transsyberyjskiej, spodziewając się nawiązania kontaktu w rejonie Wiatki z siłami brytyjskimi posuwającymi się z Archangielska na południe wzdłuż rzeki Dwiny ${ }^{68}$. Opanowane przez Kołczaka tereny Azji Centralnej ${ }^{69}$ to $\mathrm{w}$ znacznej części obszary zamieszkałe przez ludność muzułmańską: Tatarzy nadwołżańscy i Baszkirowie to grupy największe, ale nie jedyne; żyli w rozproszeniu, wśród Rosjan i innych nie-muzułmanów. Kołczak zaś nie podjął żadnej próby pozyskania lokalnych narodowości oraz miejscowych społeczności dla swojego programu i celów. Program Kołczaka był po prostu reakcyjny. Bolszewicy zaś i wówczas, i później wykazywali duże zainteresowanie i umiejętność pozyskiwania tych narodowości ${ }^{70}$. Były to obszary

${ }^{66}$ Korpus Czechosłowacki w Rosji: z jeńców austro-węgierskich narodowości czeskiej i słowackiej utworzono liczący 50-60 tys. żołnierzy korpus, który Ententa uznała za część swoich sił zbrojnych; przy korpusie działało przedstawicielstwo Czechosłowackiej Rady Narodowej. W lutym 1918 r. dowództwo korpusu zawarło z bolszewikami porozumienie o ewakuacji jednostek korpusu przez Syberię i Daleki Wschód na front francuski (w kierunku zachodnim były wojska niemieckie). Podczas transportu kolejowego dochodziło do incydentów; w kwietniu 1918 r. bolszewicy zażądali rozbrojenia korpusu; w maju 1918 r. korpus opanował rejon Czelabińska (co niektórzy badacze chcą uważać za początek rosyjskiej wojny domowej); walki toczyły się wzdłuż całej magistrali kolejowej; 8 czerwca 1918 r. korpus wkroczył do Samary; 29 czerwca 1918 r. pierwsze eszelony były we Władywostoku; 6-7 sierpnia 1918 r. korpus zajął Kazań, gdzie zdobyto narodowy skarbiec rosyjski (ok. $700 \mathrm{mln}$ rubli w złocie); dowódcy korpusu stanęli na czele oddziałów podporządkowanych admirałowi A. Kołczakowi; w 1920 r. korpus opuścił Rosję. A. Lityński, op. cit., s. 340.

${ }^{67}$ Aleksandr Wasiljewicz Kołczak (1873-1920), pochodził z Tatarów krymskich, ale urodził się koło Petersburga, ukończył Korpus Kadetów; badacz polarny oraz syberyjski, autor poświęconych im prac; w czasie wojny rosyjsko-japońskiej ranny w obronie Portu Artura; w czasie I wojny światowej dowodził marynarką wojenną na Bałtyku i Morzu Czarnym; od 1917 admirał; od 18 listopada 1918 Wielkorządca Rosji; zorganizował armię, która zajęła znaczną część Syberii i Ural i dotarła (marzec 1919) w rejon Wołgi; zamiast koordynacji działań z Denikinem K. chciał pierwszy zająć Moskwę i poniósł klęskę od Armii Czerwonej; 6 stycznia 1920 zrzekł się godności na rzecz Denikina; oddał się w ręce żołnierzy Korpusu Czechosłowackiego, a ci wydali go bolszewikom; rozstrzelany 7 lutego 1920 w Irkucku; WEP XIV, s. 160; Leksykon historii świata ..., s. 134; G. Przebinda, J. Smaga, Kto jest kim w Rosji po 1917 roku ..., s. 139.

${ }^{68}$ G. Swain, Wojna domowa w Rosji, tłum. Z. Simbierowicz, Warszawa 2007, s. 96.

69 Ten ogromny obszar wcześniej nazywany był „Tatarią”. Termin „Azja Środkowa”, bądź „Azja Centralna” pojawił się w XIX w. za sprawą głównie geografów i podróżników niemieckich i współistniał z innymi jeszcze nazwami regionu. Zob. J. Rohoziński, Bawetna, samowary i Sartowie. Muzulmańskie okrainy carskiej Rosji 1795-1916, Warszawa 2001, s. 45-46.

${ }^{70}$ Zob. m.in. hasło: Наркомнаи (Народный комиссариат по делам национальностей, 1917-1923), [w:] Энциклопедия государства и права. Ред. П. Стучка, Издательство Коммунистической Академии, t. 2, Москва 1930, s. 852 i n. 
z dawna niespokojne. „Nigdzie w imperium [Romanowych - A.L.] walka narodowa nie przybrała tak gwałtownej postaci jak tu, gdzie nacjonalizm splótł się nierozdzielnie z klasowymi i religijnymi antagonizmami"71 - pisał znawca problemu. W swojej monografii Richard Pipes poświęca wiele uwagi regionom muzułmańskim (cały rozdział IV, także część rozdziału II) i są to części dzieła bardzo interesujące dla polskiego czytelnika, bo po prostu zwykle słabiej znane ${ }^{72}$.

Zagadnieniu wielkiej rozmiarami i wielkiej zaangażowaniem międzynarodowym Republiki Dalekiego Wschodu Richard Pipes w swojej książce poświęcił dokładnie 3,5 zdania (s. 258). Utworzenie i istnienie tej gigantycznej efemerydy na ogół jest w Polsce - poza grupą specjalistów - słabo znane, toteż uzupełniając wywody Pipesa, warto tu nieco przybliżyć sprawę. To Japonia wystąpiła z inicjatywą utworzenia na Dalekim Wschodzie Rosji państwa buforowego. Celem było zarówno odgrodzenie się od rewolucji, jak też ustabilizowanie nader ważnych dla życia gospodarczego Japonii interesów gospodarczych w ogarniętej chaosem Rosji.

Po upadku Kołczaka władzę w Irkucku sprawowało Centrum Polityczne (eserowcy i mienszewicy), zaś walki toczyli wszyscy przeciwko wszystkim: Centrum ze słabymi tam bolszewikami (kierowanymi przez Dalbiuro Rosyjskiej Komunistycznej Partii (b)), Kozacy Zabajkalscy atamana Siemionowa (biali), silne grupy partyzanckie (zarówno przeciwko czerwonym, jak i białym), 5 armia Armii Czerwonej; do tego doszły duże siły Korpusu Czechosłowackiego; oddziały japońskie zaś zajęły (kwiecień 1920 r.) kluczowe punkty we Władywostoku i na terenie Przymorza. Pod patronatem Armii Czerwonej Zjazd Pracujących Przybajkalia w Wierchnieudińsku (stacja Kolei Transsyberyjskiej, na południowy wschód od Jeziora Bajkał; później Ułan-Ude) 6 kwietnia 1920 r. proklamował utworzenie Republiki Dalekiego Wschodu i powołał Rząd Tymczasowy, uznany wkrótce przez władze w Moskwie. W Dalbiurze RKP(b) były w tym zakresie ostre podziały. Znowu zwyciężył pragmatyzm Lenina, który zdawał sobie sprawę, że bolszewicy na Zabajkalu nie są w stanie przeciwstawić się siłom atamana kozackiego Siemionowa, ani resztkom sił pokołczakowskich ${ }^{73}$. Republika Dalekiego Wschodu miała swoją Ludową Armię Rewolucyjną RDW, składającą się z jednostek Armii Czerwonej.

Obszar tego marionetkowego państwa rozciągającego się „na wschód od Jeziora Bajkał" (tylko tak oficjalnie oznaczono granice) to ponad $1,5 \mathrm{mln} \mathrm{km}^{2}$, ludność ok. 1,8 $\mathrm{mln}^{74}$.

71 R. Pipes, Czerwone imperium..., s. 84.

${ }^{72}$ Od strony prawnej rozpracował je niegdyś W. Suchecki, op. cit., s. 134 i n., passim.

${ }^{73}$ W. Materski, Bolszewicy i samuraje. Walka dyplomatyczna i zbrojna o rosyjski Daleki Wschód (1917-1925), Warszawa 1990, s. 71-80; zob. też W. Lenin, Dzieła wszystkie, t. 41, s. 126.

${ }^{74}$ WEP XXIII, s. 282-283. 
Dalbiuro RKP(b) dokonywało stopniowej sowietyzacji Republiki Dalekiego Wschodu. W tle była wielka polityka światowa, a zwłaszcza amerykańsko-japońska rywalizacja o wpływy w obszarze Oceanu Spokojnego oraz o dostęp do Chin. Skończyło się typowo: Republika Dalekiego Wschodu poprosiła (czerwiec 1922 r.) o włączenie do Rosyjskiej SFRR. Tyle uwag o Republice Dalekiego Wschodu, wypowiedzianych celem uzupełnienia treści książki Richarda Pipesa.

XI. Nieulegające wątpliwości nasilenie dążeń niepodległościowych, po skutecznym zamachu bolszewickim, będące po części - paradoksalnie - efektem problemów klasowych, było mianowicie wywołane tendencją do oderwania się nie tylko i może niekiedy nie tyle nawet od Rosji (przykładem Armenia), co oderwaniem się od rosyjskich porewolucyjnych porządków ustrojowych, (bez)prawnych, gospodarczych. Richard Pipes w swojej książce wygłosił ciekawą myśl, że ówcześnie „w warunkach, w jakich federalizm został zastosowany, oznaczał on krok w stronę centralizacji” (s. 245). Spostrzeżenie to uważam za trafne, chociaż należałoby jednym tchem dodać, że chodzi o federalizm w fałszywym radzieckim wydaniu, chodzi o fikcję federalizmu.

Richard Pipes prowadzi też wykład na temat roli partii komunistycznej w centralizacji tworu z nazwy federalnego. Pomimo że nie sposób odmówić trafności wywodu, to jednak generalna teza o nadrzędności partii nad organami państwa jest wręcz oczywista, a dla osób starszego pokolenia znana także z autopsji. Odkrywcza dla nas nie jest; może inaczej dla Amerykanów. Przy okazji wywodów na temat roli partii w systemie ustrojowym i centralizacji rzekomo federalnego systemu warto byłoby poświęcić nieco uwagi splataniu się władzy partyjnej i państwowej. Pisała o tym m.in. twórczyni teorii totalitaryzmu Hannah Arendt, wskazując na „osiągnięcie całkowitego zespolenia partii z państwem przez obsadzenie wszystkich urzędów członkami partii” i dalej: „cała rzeczywista władza jest skupiona w instytucjach ruchu, poza aparatem państwowym i wojskowym"75. Pewien niedosyt po lekturze książki Richarda Pipesa można odczuwać w obszarze roli terroru, a więc organów bezpieczeństwa. W istocie oba te, związane ze sobą, zagadnienia są niemal nieobecne. Owszem, jest terror i zbrodnie, ale jako uboczne i niezaplanowane efekty działań zbrojnych, działań wojennych. Czeriezwyczajka jest w książce nieobecna, a przecież wśród historyków można spotkać głosy, że ten organ w rękach Feliksa Edmundowicza uratował władzę bolszewików. To prawda, że bardziej uratował w samej Rosji niż na peryferiach imperium, ale jednak. „Ponad państwem i poza fasadami pozornej władzy, w labiryncie zwielokrotnionych urzędów, pośród chaosu niewydolności tkwi jądro władzy w kraju: super

${ }^{75}$ H. Arendt, Korzenie totalitaryzmu, thum. D. Grinberg i M. Szawiel, t. 2, Warszawa 2008, s. 175. 
skuteczne i super kompetentne służby tajnej policji, decydujące o wszystkich przesunięciach we władzy" "76. Totalitarny terror stanowi system nerwowy totalitaryzmu ${ }^{77}$. Szkoda więc, że w książce Richarda Pipesa cisza na ten temat.

Jak już kiedyś o tym pisałem ${ }^{78}$, wypadnie podzielić pogląd, że od 1917 do co najmniej 1924 r. ,granica między federacją opartą na zasadzie autonomii i federacją państw suwerennych nie była wyraźnie zarysowana" ${ }^{97}$. Fikcją ${ }^{80}$ była nie tylko federacja, lecz także autonomia, nawet w sensie formalnoprawnym, mimo że pojawiały się efemeryczne republiki autonomiczne. W wielu częściach Republiki Rosyjskiej silne tendencje i naciski narodowościowe ${ }^{81}$ wymuszały uznanie autonomii ${ }^{82}$. Oprócz republik autonomicznych istniały obwody autonomiczne, ale ich istota prawna w pierwszych latach władzy bolszewików była niesprecyzowana i niejasna. Niektóre obwody autonomiczne przekształcano w republiki autonomiczne ${ }^{83}$. Niektóre rejony zaś awansowano do szczebla autonomicznych obwodów, inne łączono, jeszcze innym zmieniano nazwę. Przykładowo: w związku z późniejszą akcją osiedleńczą Żydów radzieckich - dekretem CKW z 7 maja 1934 r. przekształcono Rejon Birobidżański w Żydowski Obwód Autonomiczny ${ }^{84}$. W pewnych przypadkach nastąpiło podporządkowanie republik autonomicznych jednostkom administracyjnym ${ }^{85}$.

Leninowską zmienność stanowiska w kwestii narodowościowej zauważono już dawno ${ }^{86}$. Przed wybuchem I wojny światowej (1913 r.) był zdecy-

76 H. Arendt, op. cit., t. 2, s. 176.

77 C.J. Friedrich, Z.K. Brzezinski, Totalitarian Dictatorship and Autocracy, Cambridge 1956, s. 132 i passim.

78 Zob. A. Lityński, op. cit., wyd. 2, s. 44 i n.

79 W. Suchecki, op. cit., s. 138; zob. też V.M. Chkhikvadze, The Soviet State and Law, thum. Y. Sdobnikov, Honolulu 2000, s. 108.

${ }^{80}$ Jest niebywałe, że w fikcyjne rozwiązania radzieckiego prawa na papierze do dzisiaj wierzą niektórzy zachodni uczeni, nie dostrzegając totalnego kłamstwa. Zob. stosunkowo niedawno wydaną książkę profesora prawa na uniwersytecie stanowym w Ohio - J. Quigley, Soviet Legal Innovation and the Law of the Western World, New York 2007.

${ }^{81}$ Zob. J.N. Hazard, A Constitution for „Developed Socialism”, [w:] Soviet Law after Stalin, red. D.D. Barry, G. Ginsburgs, P.B. Maggs, cz. 2: Social Engineering Through Law, Alphen aan den Rijn-The Netherlands 1978, s. 4.

${ }^{82}$ О.И. Чистяков, Проблемы демократии и федерализма в первой советской конституции, Издательство Московского Университета, Москва 1977, s. 92 і n.; История отечественного государства и права, ч. 2..., s. 158, zob. też s. 155, 159.

83 Zob. W. Suchecki, op. cit., s. 131 i n.

${ }^{84}$ W składzie Rosyjskiej FSRR (obecnie Dalekowschodni Okręg Federalny) utworzono 7 maja 1934 r. Żydowski Obwód Autonomiczny ze stolicą w Birobidżanie. Jest to terytorium nad rzeką Amur, przy granicy z Chinami, na trasie kolei transsyberyjskiej; prehistorycznie to kraj Tunguzów. Powierzchnia ŻOA - zwanego Birobidżanem - to $36100 \mathrm{~km}^{2}$, ludność w 2002 r. liczyła 190915 osób, gęstość zaludnienia 5,3 osób na $\mathrm{km}^{2}$; według danych z 2002 r. Rosjanie stanowili 89,9\%, Ukraińcy - 4,4\%, Żydzi - 1,2\%, Tatarzy - 0,6\%. Języki urzędowe to rosyjski i jidysz.

85 W. Suchecki, op. cit., s. 121, 137; por. też V.M. Chkhikvadze, op. cit., s. 108 i n.

${ }^{86}$ M. Waldenberg, Kwestie narodowe w Europie Środkowo-Wschodniej. Dzieje. Idee, Warszawa 1992, s. 251, a także s. 248 i n.; zob. też tenże, Rewolucja i państwo w myśli politycznej W. Lenina, Warszawa 1978, s. 407 i n., passim; W. Suchecki, op. cit., s. 41, passim. 
dowanie przeciwny federacyjnej formie państwa ${ }^{87}$. Stalin, dominująca postać $\mathrm{w}$ formułowaniu koncepcji w sprawach narodowościowych ${ }^{88}$, wysunął projekt inkorporacyjny, tj. włączenia wszystkich satelickich republik do RFSRR i ich autonomizacji. Jak wspomniano, projekt wywołał ostre kontrowersje wewnątrz samej partii komunistycznej ${ }^{89}$ (o czym pisze obszernie Richard Pipes). Jak o tym kiedyś pisałem ${ }^{90}$, kategorycznie przeciwstawił się temu Lenin $^{91}$, idący wówczas - po powstaniu kronsztadzkim - w kierunku mniej czy bardziej pozorowanego liberalizmu. Takim pozorowanym na liberalizm rozwiązaniem był model federacyjny państwa $\mathrm{z}$ bardzo silną władzą centralną. Lenin polecił stworzyć „federację równoprawnych republik" ${ }^{2}$. Komisja KC przepracowała projekt rezolucji w myśl wskazań Lenina i w grudniu $1922 \mathrm{r}$. Plenum KC RKP (b) przyjęło uchwałę o zjednoczeniu republik na zasadach leninowskich ${ }^{93}$. Niemałe znaczenie miały sprawy gospodarcze ${ }^{94}$.

Richard Pipes bardzo szczegółowo, w oparciu o dokumenty, przedstawia konflikty między bolszewikami na tle przygotowywanych w 1922 r. rozwiązań przyszłej federacji. Sprawy to w generaliach znane, ale dokładność wykładu Richarda Pipesa w materii politycznej (nie prawnej) budzi uznanie. Warto w tym miejscu dodać nieco szczegółów natury prawnej, o co w pracy nie-prawnika trudniej. W listopadzie 1922 r. Biuro Polityczne KC RKP (b) zaaprobowało Zasady konstytucji ZSRR (Основные пункты Конституции $C(C P)$, na podstawie których kilka tygodni później specjalna komisja $\mathrm{KC}$ RKP(b) opracowała projekty Deklaracji oraz Umowy o utworzeniu ZSRR. Jak już wzmiankowano, 13 grudnia 1922 r. w Baku, na I Zakaukaskim Zjeździe Rad Delegatów Azerbejdżanu, Gruzji i Armenii została utworzona Zakauka-

87 W. Lenin, Uwagi krytyczne w kwestii narodowej, [w:] Dzieła wybrane, t. 1. Warszawa 1978, s. 845; zob. też M. Waldenberg, s. 256-257; por. J.N. Hazard, The Evolution of the Soviet Constitution..., s. 97.

88 J.N. Hazard, The Evolution of the Soviet Constitution..., s. 98.

89 История отечественного государства и права, ч. 2..., s. 161; Д.А. Гайдуков, Развитие советской конституции. „Советское Государство и Право”, 1957, Nr 11, s. 64; zob. też T. Szymczak, Ustrój polityczny Związku Socjalistycznych Republik Radzieckich (1936-1976), Wrocław-Warszawa-Kraków-Gdańsk 1978, s. 29-30; A. Sylwestrzak, Rozwój federacji radzieckiej (1922-1982), „Państwo i Prawo”, 1982, z. 12, s. 8-11.

${ }^{90}$ A. Lityński, op. cit., s. 51.

91 Zob. P. Wieczorkiewicz, [w:] L. Bazylow, P. Wieczorkiewicz, Historia Rosji, Wrocław 2005, s. 411; M. Smoleń, Stracone dekady. Historia ZSRR 1917-1991, Warszawa-Kraków 1994, s. 73-74; J.N. Hazard, The Evolution of the Soviet Constitution..., s. 97-98.

92 W. Lenin, Dzieła wszystkie, t. 45, s. 209; zob. też Д.А. Гайдуков, Развитие советской конституции, s. 65.

93 Д.А. Гайдуков, Развитие советской конституции..., s. 65; История отечественного государства и права, ч. 2, s. 162.

94 История отечественного государства и права, ч. 2, s. 155-157; zob. też J.N. Hazard, The Evolution of the Soviet Constitution..., s. 97-98; V.M. Chkhikvadze, op. cit., s. 93-94; W. Suchecki, op. cit., s. 140; S. Bożyk, Konstytucjonalizm radziecki-drogi rozwoju, ZN Filii UW w Białymstoku, 1981, nr 33, s. 14. 
ska Socjalistyczna Federacyjna Republika Radziecka oraz tego samego dnia uchwalona jej konstytucja ${ }^{95}$.

Ostatni zjazd rad rosyjski (wszechrosyjski) odbył się natychmiast (obradował 23-27 grudnia). Referat główny, zatytułowany $O$ zjednoczeniu republik radzieckich, wygłosił Ludowy Komisarz ds. Narodowości - Stalin i zgodnie z przyjętymi już zasadami leninowskimi oznajmił m.in., że ,podmiotami jednoczącymi się w związek powinny być cztery republiki: RSFRR, Federacja Zakaukaska, Ukraina i Białoruś" ${ }^{96}$. Referat Stalina mieścił w sobie bliższe określenie większości zasad organizacji państwa. Kończył Stalin wyrażeniem nadziei, ,że nowe państwo związkowe będzie nowym stanowczym krokiem na drodze do zjednoczenia mas pracujących całego świata w Światową Socjalistyczną Republikę Radziecką" 97.

I Zjazd Rad ZSRR w dniu 30 grudnia 1922 r. uchwalił wcześniej przygotowane i podpisane dwa dokumenty - Deklarację o utworzeniu Zwiazku Socjalistycznych Republik Radzieckich oraz Umowe o utworzeniu Zwiazku Socjalistycznych Republik Radzieckich ${ }^{98}$. Była kompromisem między tendencjami centralizacyjnymi a tymi niechcącymi zaakceptować hasła Manifestu komunistycznego: „robotnicy nie mają ojczyzny”"99. W efekcie wymieszane były rozmaite elementy ustrojowe ${ }^{100}$. Struktura ZSRR formalnie stanowiła mieszaninę zasad federacji i konfederacji ${ }^{101}$.

Już bardzo dawno zauważono, że zasadniczym problemem konstytucyjnym (dodajmy: i nie tylko konstytucyjnym) Rosji radzieckiej była wówczas kwestia narodowa ${ }^{102}$. Cała książka Richarda Pipesa potwierdza to spostrzeżenie, wnosząc wiele nieznanych nam, albo znanych słabo lub fragmentarycznie informacji, faktów. Richard Pipes w zakończeniu pisze: „Związek Sowiecki z roku 1923 był kompromisem między doktryną a rzeczywistością, próbą pogodzenia bolszewickich dążeń do absolutnej jedności i centralizacji całej władzy w rękach partii ze stwierdzonym empirycznie faktem, że uczucia narodowe przetrwały upadek starego porządku" (s. 300). Trudno się z tym nie zgodzić, a chyba warto jeszcze dodać, że uczucia z reguły stają się mocniejsze, jeśli dostrzega się burzenie świata, którego uczucia te dotyczą.

95 История советской конституциии (в документах) 1917-1956..., s. 374 і n.; История советской конституциии. Сборник документов. 1917-1957..., s. 195 i n.

96 J. Stalin, Dzieła, t. 5, s. 159.

97 Ibidem, s. 162 [podkreślenie moje - A.L.]; zob. też A. Lityński, op. cit., s. 53.

98 История советской конституцчии (в документах) 1917-1956..., s. 391-398; История советской конституции. Сборник документов. 1917-1957..., s. 213-218; zob. też A. Sylwestrzak, Rozwój federacji radzieckiej..., s. 11; V.M. Chkhikvadze, op. cit., s. 95.

99 Zob. J.N. Hazard, A Constitution for „,Developed Socialism ”..., s. 4.

100 W.E. Butler, Soviet Law, London 1983, s. 145.

101 Ibidem, s. 144.

102 Z. Jarosz, Uwagi wstępne do rozdziału Związek Socjalistycznych Republik Radzieckich, w: Konstytucje europejskich państw socjalistycznych. Zbiór tekstów pod redakcją Andrzeja Burdy. Wrocław-Warszawa-Kraków 1967, s. 292; także S. Bożyk, op. cit., s. 14. 
Jak niemal wszystkie prace Richarda Pipesa, monografia Czerwone imperium. Powstanie Zwiąku Sowieckiego jest materiałowo nader cenna, wnosi do naszej wiedzy nowe informacje, ale także i spostrzeżenia Autora o rosyjskiej rewolucji sprzed 100 lat i niektórych dalszych jej konsekwencjach. 